\title{
Szájüregi manifesztációk primer immundeficientiákban
}

\author{
Szegedi Márta dr. ${ }^{1}$ - Erdős Melinda dr. ${ }^{2,4}$ - Tar Ildikó dr. ${ }^{3}$ \\ Debreceni Egyetem, ${ }^{1}$ Fogorvostudományi Kar, Fogpótlástani Tanszék, ${ }^{2}$ Általános Orvostudományi Kar, \\ Infektológiai és Gyermekimmunológiai Tanszék, ${ }^{3}$ Fogorvostudományi Kar, Orális Medicina Tanszék, Debrecen \\ ${ }^{4}$ St. Giles Laboratory of Human Genetics of Infectious Diseases, The Rockefeller University, New York, NY, \\ Amerikai Egyesült Államok
}

\begin{abstract}
Primer immundeficientiákban a társuló szájüregi manifesztációk leggyakrabban fogágybetegség, fogszuvasodás és szájnyálkahártya-betegségek formájában jelentkeznek. A fogszuvasodás kialakulására való fokozott hajlam elsősorban az immunglobulintermelés zavarával járó immunhiány-betegségeket jellemzi, míg a plakk jelenlétéhez köthető fogágybetegség phagocytadefektusokban gyakori. A fogak szerkezeti rendellenessége az apoptózis zavarával járó immunhiányos betegségekben fordulhat elő. A DNS-repair-mechanizmusok defektusával járó immundeficientiákban rosszindulatú szájüregi daganatok is kialakulhatnak.
\end{abstract}

Orv Hetil. 2018; 159(49): 2079-2086.

Kulcsszavak: primer immundeficientia, szájüregi betegségek

\section{Oral manifestations in patients with primary immunodeficiencies}

Characteristic lesions of the oral cavity in primary immunodeficiencies are commonly found in the form of periodontal disease, tooth decay and disorders of the oral mucosa. Humoral immunodeficiencies may cause tooth decay, while severe forms of plaque-induced periodontal disease are common in phagocytic deficiencies. The structural abnormalities of the teeth can occur in immunodeficiencies associated with apoptosis defect. Oral squamous cell carcinoma is a possible complication of immunodeficiencies associated with DNA repair defects.

Keywords: primary immunodeficiencies, oral disorders

Szegedi M, Erdős M, Tar I. [Oral manifestations in patients with primary immunodeficiencies]. Orv Hetil. 2018; 159(49): 2079-2086.

(Beérkezett: 2018. július 20.; elfogadva: 2018. augusztus 9.)

\section{Rövidítések}

$\mathrm{AD}=$ autoszomális domináns; APECED = autoimmun polyendocrinopathia, candidiasis, ectodermalis dystrophia; $\mathrm{AR}=\mathrm{au}-$ toszomális recesszív; CANDLE $=$ (chronic atypical neutrophilic dermatitis with lipodystrophy and elevated temperature) krónikus atípusos neutrophil dermatosis lipodystrophiával és emelkedett testhómérséklettel; CGD = (chronic granulomatous disease) krónikus granulomás megbetegedés; CMC = (chronic mucocutaneous candidosis) krónikus mucocutan candidiasis; CVID = (common variable immunodeficiency) gyakori változó immundeficientia; EDA-ID = anhidrotikus ectodermalis dysplasia immundeficientiával; HIGE = (hyper-IgE syndrome) hiper-IgE-szindróma; Ig = immunglobulin; IUIS = (International Union of Immunological Societies) Immunológiai Társaságok Nemzetközi Szövetsége; LAD = (leukocyte adhesion deficiency) fehérvérsejt-adhaesiós defektus; NADPH $=$ (nicotinamide adenine dinucleotide phosphate) nikotinamidadenin-dinukleotid-foszfát; PID $=$ (primary immunodeficiency) primer immundeficientia; SCID $=($ severe combined immunodeficiency) súlyos kombinált immundeficientia; $\mathrm{TNF} \alpha=$ tumornekrózisfaktor-alfa

Az egyes primer immundeficientiák (PID) ritka kórképek, összességében azonban az előfordulási gyakoriság magas, és egyre emelkedik. Míg a súlyos kombinált immundeficientia (SCID) előfordulási gyakorisága 1 : 300 000, addig a leggyakoribb immundeficientia, a szelektív immunglobulin A (IgA) hiánya 300-700-ból 
egy embert érint. Az esetek többségében az immunológiai alapbetegség már ismert, amikor a beteg fogorvoshoz fordul [1]. Az immundefektusok kezelése egyre hatékonyabb, és folyamatosan nő a betegek várható élettartama. Ez a kedvező változás egyben azt is jelenti, hogy a PID-ben szenvedő betegek növekvő számban veszik igénybe a fogászati szakellátásokat.

A szájüregi betegségek közül PID-ben leggyakrabban a fogágy betegségei, a fogak kemény szöveteit érintő, szövethiányt okozó fogszuvasodás, illetve a szájnyálkahártya különféle elváltozásai fordulnak elő [2, 3]. Egyes immunhiány-betegségekben harapási rendellenesség, a fogak szerkezeti rendellenessége (zománc-, dentin- és cementhipokalcifikáció, hypoplasia) vagy rosszindulatú daganatok (elsősorban szájüregi laphámcarcinoma) kialakulása jellemző [4]. Ritkán koponyafejlődési rendellenesség és dysmorph arc színezi a klinikai képet.

A közlemény a foobb szájüregi betegségek patomechanizmusának rövid ismertetését követően a veleszületett immunhiány-betegségekben előforduló szájüregi manifesztációkat foglalja össze az IUIS (International Union of Immunological Societies - Immunológiai Társaságok Nemzetközi Szövetsége) legutóbbi klasszifikációja szerinti PID-felosztást követve $[5,6]$.

\section{A fogágybetegség patomechanizmusa}

A fogágybetegség, vagy más néven parodontalis betegség, a fogágy (a gingiva, a ligamentum parodontale, a processus alveolaris és a gyökércement) részeinek gyulladása, amely kezelés nélkül a fogágy szöveteinek pusztulásához és a fogak elvesztéséhez vezet. A jelenleg használt klasszifikáció szerint a parodontalis megbetegedéseket a patomechanizmus alapján az alábbi csoportokra osztjuk: 1) az úgynevezett 'plakk okozta' fogágybetegségek, amelyek esetében a fogágygyulladás megjelenése függ a dentális plakkban lévő baktériumok összetételétől és számától, tehát szájhigiéné-függő; 2) úgynevezett 'nem plakk okozta' fogágybetegségek, amelyek szisztémás autoimmun betegségekben, a szájüreggel kontaktusba kerülő anyagokra kialakuló allergiákban, illetve mucocutan szindrómákban fordulnak elő, tehát kialakulásukban a szájhigiéné minősége nem meghatározó [7]. A fogágybetegségek szisztémás hátterú, súlyos formáját a korábbi, 1989-es klasszifikáció a praepubertalis jelzővel illette, utalva a folyamat életkori sajátosságaira, míg a legújabb osztályozás ezt a formát a szisztémás betegségek tüneteként megjelenő fogágybetegségként említi [7].

A dentális plakk okozta fogágybetegség a szájüregi baktériumok és az immunrendszer közötti kölcsönhatás következménye. Jó szájhigéné mellett a fogágy bacterialis stimulációja kisfokú; a plakk fóleg Gram-pozitív baktériumokból áll, az ínyszélben kialakuló immunválasz kismértékü, és elsősorban a phagocyták jelenléte jellemző. Ez az állapot az immunrendszer előaktivált állapotának felel meg, klinikailag pedig fiziológiás állapotnak, vagyis ínyvérzés nem jellemző, az íny rózsaszínű, és kés- pengeszerüen végződik a fognyakon [8]. A plakk önmagától nem válik le, csak megfelelő mechanikus szájhigénével (fogkefe és fogköztisztító eszközök használatával) távolítható el, így ezek hiányában van idő a bacterialis egyensúly megváltozására. A plakkban már 2 nap után megjelennek a periodontopathogen baktériumok (Aggregatibacter actinomycetemcommitans, Prevotella nigrescens, Porphyromonas gingivalis, Tannerella forsythia, Flavobacterium nucleatum, Treponema pallidum), és 14 nap után gyakorlatilag csak ezek alkotják a plakkot [9]. A baktériumok epitheliotoxinjaik segítségével képesek a gingiva hámján átjutni, vagy bizonyos bacterialis alkotóelemeik (például lipopoliszacharidok) lépnek át a hámbarrieren. A baktériumok és alkotóelemeik eliminációjához a neutrophil granulocyták tökéletes múködése elengedhetetlen. A neutrophil sejtek degranulációja során a környező fogágyszövetekbe is történik enzimürítés, de ezt a normális immun- és regeneratív funkciók képesek kompenzálni. A bacterialis lipopoliszacharidok a monocytákat is stimulálják, amelyek interleukinok (például ILI $\beta$ ), arachidonsav-anyagcseretermékek (például prosztaglandin E2) és tumornekrózisfaktor- $\alpha$ (TNF $\alpha$ ) termelésével vesznek részt a bacterialis antigének eltávolításában és a gyulladásos válaszreakció beindításában. A gyulladásos folyamat során a szövetbontó enzimek (például mátrixmetalloproteinázok) kóros aktivitása miatt jellemző a kollagén rostok fokozott lebontása és az osteoblast-osteoclast egyensúly eltolódása a lebontás irányába. Fogágybetegségben tehát a szövetek destrukciója három lépésben történik: a direkt bacterialis destrukciót a phagocyták degranulációja és a szövetek gyulladása követi [8].

Minél fiatalabb életkorban jelenik meg a fogágybetegség, és minél gyorsabb progressziót mutat, annál valószínúbb, hogy a háttérben valamilyen veleszületett phagocytadefektus áll [10]. Fontos a fogágy alapos vizsgálata parodontalis szondával, mert előfordulhat, hogy a súlyos immunhiányos állapot ellenére a fogágy egészségesnek, gyulladásmentesnek túnik. PID esetén a fogágybetegség rendszerint már a tejfogazatot is érinti [11]. Az összes tejfog átlagosan kétéves korra tör elő. Az érintett gyermekekben a fogágyfolyamat az íny gyulladásával (gingivitis) kezdődik, majd ráterjed a fogágy többi szövetére is (parodontitis). Az íny hámtapadása a gyökércsúcs irányába vándorol (= tapadásveszteség), amit az tesz lehetôvé, hogy a tőle a gyökércsúcs irányában elhelyezkedő szövetek - mint a ligamentum parodontale és a processus alveolaris csontja - a mátrixmetalloproteinázok fokozott aktiválódása miatt elpusztulnak. A gyökércement a szövetpusztulás felőli felszínen nekrotizál, így a fogak megtámasztása fokozatosan csökken. Idővel az élettani erő is túlterheli a fogakat, így könnyen sérülnek. A gyulladás az elötörés sorrendjében érinti a fogakat, és a gyermekek többnyire ebben a sorrendben is veszítik el fogaikat. Súlyos esetben a gyermek négyéves korára teljesen fogatlanná válik. Ezekben az esetekben a maradó fogazat is rendszerint súlyosan érintett, amely akár már 13 éves kor 
körül a teljes fogazat elvesztéséhez vezethet [12]. Kevésbé súlyos esetben a fogvesztés kisebb mértékü, de kifejezett szövetpusztulás a fogak körül többnyire ekkor is látható [12].

\section{Fogszuvasodás és zománceltérések}

A caries kialakulása a dentális plakkot kolonizáló Grampozitív baktériumok (elsősorban Streptococcus mutans és Lactobacillusok) savtermelésének következménye, amelyek a táplálékban található finom szénhidrátokat bontják le savvá. Ennek hatására a szájüregi pH az úgynevezett kritikus pH $(5,4-5,7)$ alá csökken. A fogfelszín a szervetlen állomány kioldódása miatt porózussá válik. A folyamat ekkor még reverzibilis, mivel a felszín szerves állománya még intakt, és megfelelő $\mathrm{pH}$ esetén a szivacsos szerkezetű rész képes a szervetlen anyagok visszaépítésére. Amikor a fog szerves állománya is érintett lesz, a folyamat irreverzibilissé válik, és megindul az üreg képződése, amelyben további baktériumok telepednek meg. Míg a Streptococcusok elsősorban a szuvasodás elindításában játszanak szerepet, addig a Lactobacillusok a $\mathrm{pH}$ további csökkentésével a folyamat fenntartásáért és a szövetdestrukció felgyorsításáért felelősek [13]. A fogszuvasodás kialakulásában a mikrobiológiai faktorokon kívül a fogzománc minősége is meghatározó tényező. Fontos, hogy a zománcnak mennyi a szervetlenanyagtartalma, a vastagsága, milyen a felülete, és mennyire homogén a szerkezete. A fogszuvasodás folyamatát egy antibiotikumkúra is befolyásolhatja, hiszen a normálflóra megváltozása hatással van a zománcképződésre, a szájüregi flóra pedig az antibiotikumszedés után csak körülbelül 3 hónap alatt rekolonizálódik. A módosult phagocytaként müködő ameloblastok, a környezeti pH függvényében endocytosisra, tehát a környezetükben lévő anyagok, többek között szervetlen ionok és fehérjék felvételére képesek. A felvett anyagokat a sejt basalis pólusán a kialakuló zománcba szekretálják, ahol megindul a kristályképződés, elsősorban a hidroxilapatité. A szerves váz károsodása esetén hypoplasia jön létre, amely vékonyabb zománcot idéz elő. Ha azonban a szervetlen állomány is károsodik, hipomineralizált zománc jön létre, amelynek keménysége csökken, így könnyebben oldódik savas közegben [14].

\section{Szájüregi manifesztációk primer immundefektusokban}

Az IUIS klasszifikációja szerinti PID-alcsoportok a következôk: 1) kombinált immundeficientiák, 2) kombinált immundeficientiák szindrómajelekkel, 3 ) antitestdeficientiák, 4) immundiszregulációs szindrómák, 5) phagocytadefektusok, 6) a természetes immunitás veleszületett zavarai, 7) autoinflammatiós betegségek és 8) komplementdeficientiák $[5,6]$. A fejezet az egyes PIDalcsoportokra jellemző fogászati eltéréseket foglalja ösz- sze, és az adott csoportba tartozó immunhiány-betegségek közül bemutatja azokat, amelyekben az intraoralis manifesztáció különösen jellegzetes a klinikai képre ( 1 . táblázat). Általánosságban elmondható, hogy a visszatérő légúti fertőzésekre hajlamosító immunhiány-betegségekre jellemző, hogy a gátolt orrlégzés miatti gyakori szájlégzés megzavarhatja az arc fejlődését és a fogak előtörését, illetve az egészséges harapási forma kialakulását [15]. Szinte valamennyi PID-betegségben előfordulhat szájnyálkahártya-aphta, amely nem keverendő össze a neutropeniában észlelhető fekélyekkel. Az aphták kevésbé mély, sima, nem kirágott peremú és széles gyulladásos udvarral körülvett elváltozások, amelyek jelentős fájdalmat okoznak. Szövettani vizsgálat során nemspecifikus gyulladás képe látható. PID-ben leggyakrabban az úgynevezett Mikulicz-aphták fordulnak elő, amelyek körülbelül $5 \mathrm{~mm}$ átmérőjűek (1. ábra).

Kombinált immundeficientiák: Kombinált immundefektusokban a cellularis és a humoralis immunitás egyaránt érintett. A T-sejteket is érintő immundefektusokra a nekrotizáló-ulceratív fogágybetegség és a fekélyképződés jellemző, gyakori a fogak körüli fekélykoszorú. A döntően opportunista kórokozók által okozott szájüregi fertőzések leggyakrabban pseudomembranosus candidiasis formájában észlelhetők. A szájnyálkahártyát fedő fehér, letörölhető hártya eltávolítása (gézlappal való letörlés) után látszik a kissé erythemás nyálkahártya, amelyen vérző pontok maradnak. A fogakhoz asszociált plakkbaktériumok a gingivitis miatt meggyengült hámon át direkt módon képesek az íny kötőszövetébe jutni. A fekélykoszorú a fogközökből indul, és a plexus gingivalisnak megfelelően az ínyszél mentén terjed a fogak körül. Ha az antibiotikumkezelés hatástalan vagy késik, a folyamat a ligamentum parodontale és a periosteum erei mentén a mélyebb szövetek irányába terjed. A klinikai képre a kifejezett fájdalom és a rendkívül erôs szájszag jellemző. A fogágybetegség ezen formája súlyos kombinált immundefektusban (SCID), úgynevezett gyakori variábilis immundefektusban (CVID), Wiskott-Aldrich-szindrómában, továbbá hiper-IgM-szindrómában (CD40- és CD40L-deficientia) fordul elő a leginkább [16]. Fiatal felnőttekben hasonló típusú fogágybetegség alakulhat ki fokozott stressz, dohányzás és rossz szájhigéné következtében. A stressz és a dohányzás növeli az adrenalin felszabadulását a mellékveséből, aminek hatására a Thlés a Th2-sejtek száma és aktivitása, valamint a mucosalis immunválasz erőssége csökken. A rossz szájhigiéné miatt fokozott a dentálisplakk-képződés és a direkt hámkárosító hatású baktériumok (Fusobacteriumok és Spirochaeták) kolonizációja, ami elősegíti a fekélyképződést [17]. $\mathrm{Az}$ úgynevezett BCL11B-kombinált immundeficientia jellegzetessége a döntően T-sejteket érintő funkciózavar mellett a neonatalis fog. A kombinált immundefektusok közül több társul a DNS-repair zavarával, emiatt hajlamosítanak szájüregi carcinoma kialakulására [18]. Di George-szindrómában a parathormon hiánya hypocalcaemiához vezet, aminek következménye a hipokalcifikált/ 


\begin{tabular}{|c|c|c|}
\hline Primer immundeficientia & Gén & Intraoralis manifesztáció \\
\hline \multicolumn{3}{|l|}{ Kombinált immundeficientiák } \\
\hline $\begin{array}{l}\text { Súlyos kombinált immundeficientia } \\
\text { Gyakori variábilis immundefektus (CVID) } \\
\text { Wiskott-Aldrich-szindróma } \\
\text { Hiper-IgM-szindróma (CD40- és CD40L-deficientia) }\end{array}$ & Típustól függ & $\begin{array}{l}\text { Nekrotizáló-ulceratív fogágybetegség, fekélyképződés, } \\
\text { oralis candidiasis }\end{array}$ \\
\hline BCL11B-deficientia & $\mathrm{BCL11B}(\mathrm{AD})$ & Neonatalis fog \\
\hline $\begin{array}{l}\text { Kromoszómatörékenységgel és/vagy DNS-repair- } \\
\text { defektussal társuló immundeficientiák }\end{array}$ & Típustól függ & Rosszindulatú szájüregi daganatok \\
\hline Di George/velocardiofacialis szindróma & 22-es kromoszóma (AD) & Hipokalcifikált/hipomaturált zománc \\
\hline $\begin{array}{l}\text { Autoszomális domináns hiper-IgE-szindróma } \\
\text { (HIES, Jób-szindróma) }\end{array}$ & STAT3 (AD LOF) & $\begin{array}{l}\text { Tejfogretentio, oralis candidiasis, parodontitis, } \\
\text { parodontalis abscessus, szájnyálkahártya-hiperkeratini- } \\
\text { záció }\end{array}$ \\
\hline Dyskerindeficientia okozta dyskeratosis congenita & $\mathrm{DKCl}(\mathrm{XL})$ & Premalignus oralis leukoplakia \\
\hline $\begin{array}{l}\text { NEMO-deficientia okozta anhidrotikus ectodermalis } \\
\text { dysplasia immundeficientiával (EDA-ID) }\end{array}$ & NEMO /IKBKG/ (XL) & Kúp alakú fogak \\
\hline Kabuki-szindróma & KMT2D /MLL2/(AD) & Szájpadhasadék vagy magas ívelt szájpad \\
\hline \multicolumn{3}{|l|}{ Antitestdeficientiák } \\
\hline A-és hypogammaglobulinaemiák & Típustól függ & Zománchypoplasia \\
\hline \multicolumn{3}{|l|}{ Immundiszregulációs szindrómák } \\
\hline Chédiak-Higashi-szindróma & LYST (AR) & Gingivostomatitis \\
\hline $\begin{array}{l}\text { APECED- (autoimmun polyendocrinopathia, candidiasis, } \\
\text { ectodermalis dystrophia) szindróma }\end{array}$ & AIRE (AR vagy AD) & Fogzománc-hypoplasia, oralis candidiasis \\
\hline \multicolumn{3}{|l|}{ Phagocytadefektusok } \\
\hline Congenitalis neutropeniák különböző típusai & Számos gén & $\begin{array}{l}\text { Szájnyálkahártya-fekély, recidiváló stomatitis, krónikus } \\
\text { gingivostomatitis }\end{array}$ \\
\hline Fehérvérsejt-adhaesiós deficientia (LAD) 1. típusa & $\operatorname{ITGB2}(\mathrm{AR})$ & Parodontitis \\
\hline$\beta$-Aktin-deficientia & FPRl (AR) & Csak parodontitis \\
\hline $\begin{array}{l}\text { Papillon-Lefevre-szindróma, } \\
\text { Lokalizált juvenilis periodontitis }\end{array}$ & CTSC (AR) & Parodontitis \\
\hline WDRl-deficientia & WDRl (AR) & Súlyos stomatitis \\
\hline Krónikus granulomás betegség (CGD) & Számos gén & Parodontitis $\rightarrow$ súlyos gingivitis \\
\hline \multicolumn{3}{|l|}{ A természetes immunitás veleszületett zavarai } \\
\hline Krónikus mucocutan candidiasis (CMC) & STATI (AD GOF) & Oralis candidiasis \\
\hline ACTl-deficientia & TRAF3IP2 (AR) & Macroglossia \\
\hline \multicolumn{3}{|l|}{ Autoinflammatiós szindrómák } \\
\hline $\begin{array}{l}\text { Az úgynevezett lázszindrómák bizonyos típusai } \\
\text { (mevalonát-kináz-deficientia és Muckle-Wells-szindróma) }\end{array}$ & $\begin{array}{l}\text { MVK (AR) és } \\
\text { NLRP3 (AD GOF) }\end{array}$ & Stomatitis aphthosa \\
\hline
\end{tabular}

Krónikus atípusos neutrophil dermatosis lipodystrophiá- $\quad$ PSMB8 (AR vagy AD) Microdontia és microstomia val és emelkedett testhőmérséklettel (CANDLE-) szindróma

$\mathrm{AD}$ = autoszomális domináns; $\mathrm{AR}$ = autoszomális recesszív; GOF = gain of function (funkciónyerő mutáció); LOF = loss of function (funkcióvesztő mutáció); XL = X-hez kötött

hipomaturált zománc kialakulása [19, 20]. A zománcfejlődési rendellenesség jól ismert a STAT3-gén-deficientia által okozott hiper-IgE (HIGE)-szindrómában is [21, 22 ]. A betegségben a zománc kialakulásáért felelős ameloblastok is érintettek, emiatt kevesebb szerves mátrix képződik, a mineralizáció időben elhúzódóvá válik, a betegek fogékonyabbak lesznek cariesre $[23,24]$. A fogképzés zavara rendszerint feltünő, a tejfogak késői exfo- liatiója miatt a fogak gyakran két sorban helyezkednek el. Abscesszus miatt is gyakran kerül sor a fogak eltávolítására [25]. HIGE-szindrómában előfordulhat a szájnyálkahártya hiperkeratinizációja is, a keratinizált hám alatt nem alakul ki gyulladás (2. ábra) [26]. A HIGE-szindrómára jellegzetes arc a tizenéves betegek csaknem mindegyikében megfigyelhető: az arcvonások durvák, az arc hemihypertrophiát sejtetően aszimmetrikus, a koponya 


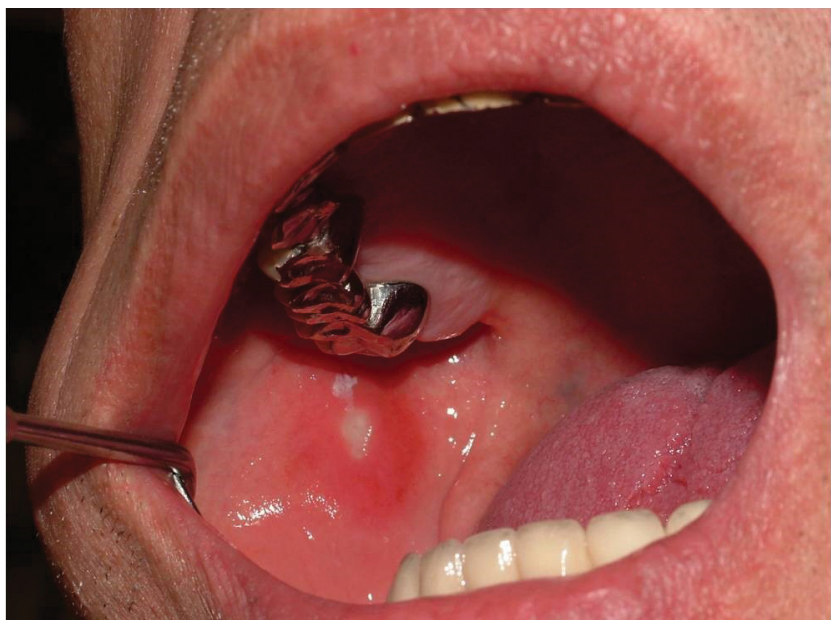

1. ábra

Aphtás fekélyek, kifejezett gyulladásos udvarral szelektív IgA hiányos betegben

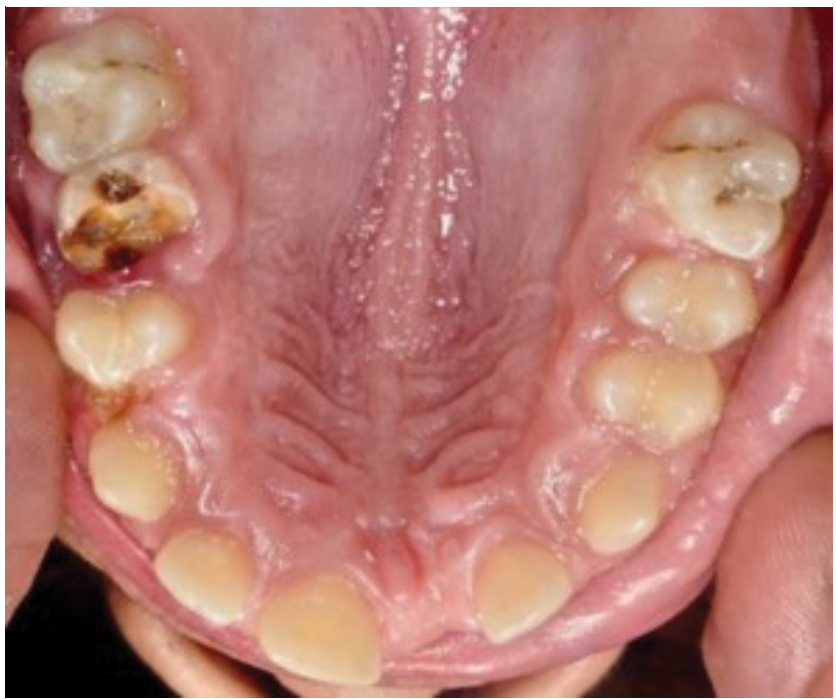

2. ábra

Hiper-IgE-szindrómás betegben hyperkeratosis miatt fehéres szájpadnyálkahártya

macrocephal, jellegzetes a széles orrhát és orrgyök, a kiugró homlok, a mélyen ülő szemek, a vastag orrszárnyak és fülek, a telt alsó ajak, az enyhe prognathia és a magas szájpad. Az arcdysmorphia részben a csont- és kötőszövetet is érintő alapfolyamat, részben a hegesedéssel gyógyuló, gennyes bőrinfekciók következménye lehet. Dyskeratosis congenita esetében elsősorban a telomerázt expresszáló és nagy sejtturnovert mutató szövetek érintettek [27-29]. A kórképre a bőr- és nyálkahártya-eltérések a legjellemzőbbek. Az úgynevezett mucocutan triász, vagyis az abnormális bőrpigmentáció, a körömdystrophia és a leukoplakia a betegek több mint 75\%-ában észlelhető. A bőr- és körömeltérések rendszerint az első dekád végére megjelennek, míg a leukoplakia általában csak a 2. vagy 3. évtizedben jelentkezik először. Ritkábban észlelt intraoralis manifesztáció a kifejezett fogszuvasodás és fogvesztés. Az anbidrotikus ectodermalis dysplasia immundeficientiával (EDA-ID) csoportba tartozó kórképekre jellemző a fogak conusos alakja. A döntően az immunglobulintermelés zavarát okozó Kabuki-szindrómában a szívfejlődési rendellenesség, az alacsonynövés, a csontvázeltérések, a szellemi fogyatékosság és az arcdysmorphia mellett gyakori a szájpadhasadék és a magas, ívelt szájpad.

Antitestdeficientiák: A humoralis immundeficientiák többsége nem hajlamosít fogágybetegség kialakulására. A PID-ben leggyakoribb szelektív IgA-hiányban például az egészséges populáció életkori átlagának megfelelő súlyosságú a társuló fogágybetegség [3, 30]. A szelektív IgA-hiányhoz gyakori társulást mutató coeliakia miatt ugyanakkor zománchypoplasia gyakrabban észlelhető, a coeliakiában termelődő autoantitestek ugyanis keresztreagálnak a zománcfehérje mátrixával, ami a felszívódási zavar okozta hiányállapotokkal együtt vezet a fogzománc gyengüléséhez [31]. A zománchypoplasia hypogammaglobulinaemiás betegekben is gyakoribb előfordulású. Antitest deficientiákban az egészséges immunrendszerú egyénekhez viszonyítva fokozott a caries kialakulására való hajlam, amely szelektív IgA-hiány esetében a legkifejezettebb. [30, 32]. Ismert, hogy az IgG2 immunglobulin befolyásolja a fogágybetegségek progresszióját. A periodontopathogenek lipopoliszacharidjainak hatására termelődő megfelelő mennyiségű és aviditású IgG2 ugyanis lassítja a betegség lefolyását $[33,34]$. Agammaglobulinaemiás állapotokban fontos prezentációs tünet a mandulaszövet teljes hiánya.

Immundiszregulációs szindrómák: Az immundiszregulációs szindrómák prototípusában, az APECED- (autoimmun polyendocrinopathia, candidiasis, ectodermalis dystrophia) szindrómában gyakori a zománchypoplasia [35]. A Chédiak-Higashi-szindrómában a lizoszomális transzport zavara miatt a neutrophil granulocytákban, de más sejtekben is a lizoszómák kóros fúziójával óriás citoplazmagranulumok jönnek létre. A pyogen fertőzések és a parciális oculocutan albinismus mellett gingivostomatitis jellemző, amely rendszerint kevés dentális plakk mellett is kialakul [36].

Phagocytadefektusok: A veleszületett immunhiány-betegségek közül leggyakrabban a phagocytadefektusokban találkozunk szájüregi tünetekkel, amelyek különösen a congenitalis, illetve a ciklikus neutropeniák esetében súlyosak. A phagocytasejtek kvantitatív vagy kvalitatív defektusai elsósorban pyogen baktériumok, illetve gombák által okozott fertőzésekre hajlamosítanak, amelyek a szájnyálkahártyát is érinthetik. A phagocytadefektusok jellegzetes tünete a nyálkahártyafekély, amely általában kevéssé fájdalmas. Neutropeniás betegben a szájüregi tünetek súlyossága és a progresszió egyértelmû összefüggést mutat a neutropenia súlyosságával $[11,12]$. Neutropenia esetén a szájnyálkahártya-fekélyek kissé kirágott szélüek, a fekély körüli gyulladásos szegély hiányzik vagy nagyon vékony, így a laesiók rendszerint fájdalmatlanok (3. ábra). Ha a neutrophil sejtszám növekszik (például terápiás hatásra), az elváltozások fájdalmassá válnak. A 4. ábrán congenitalis neutropeniás 15 éves lány fogazata 


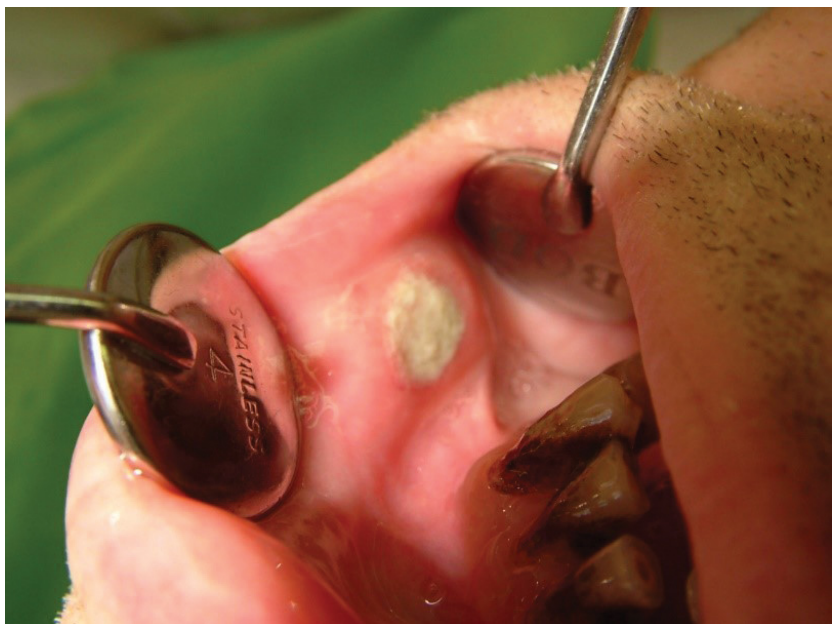

3. ábra

Szájnyálkahártya-fekély gyulladásos udvar nélkül neutropeniás betegben
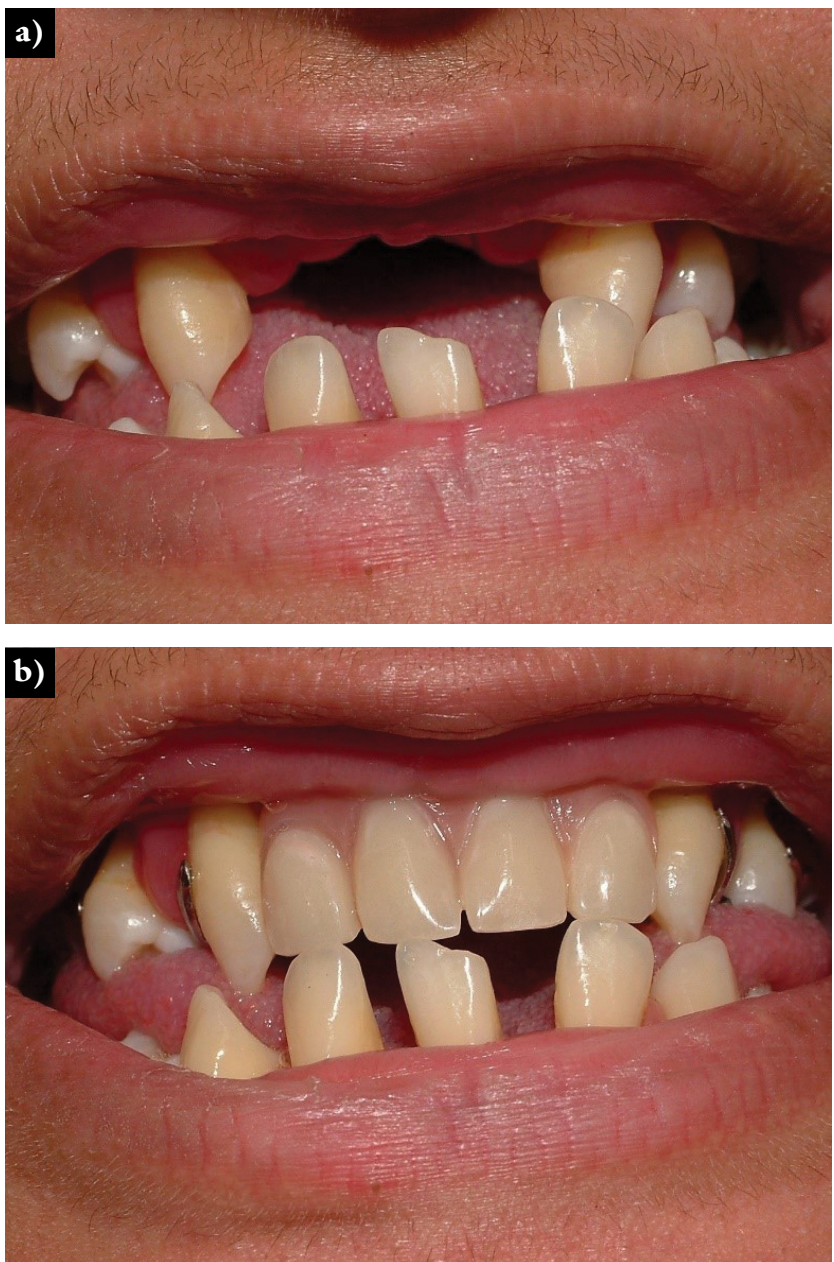

4. ábra

Congenitalis neutropeniás 15 éves lány saját fogaival (a) és kivehető fogpótlással (b)

látható, csak saját fogaival (4/a ábra) és részleges kivehetô fogpótlás készítése után $(4 / b$ ábra). A phagocyták motilitászavarával járó kórképek közül talán a legismertebb a fehérvérsejt-adhaesiós deficientia (LAD), amelynek hátterében az antimikrobás immunvédekező folyama- tokban fontos közvetlen sejt-sejt interakciók kialakításáért felelős CDll és/vagy CD18 adhaesiv molekulák defektusa áll. A betegség legjellemzőbb tünete - amely egyben prezentációs tünet is - a késői köldökzsinór-leválás (születés után több mint 2 héttel). Jellemzőek továbbá a visszatérő, súlyos bacterialis fertőzések és az elhúzódó sebgyógyulás. A LAD rendszerint súlyos, gyorsan progrediáló fogágybetegséggel társul $[10,11]$. A neutrophil granulocyták száma a perifériás vérben kifejezetten emelkedett, hiszen az adhaesiv molekulák defektusa miatt a sejtek nem tudnak kilépni az érpályáról és a gyulladás helyszínére vándorolni. A krónikus granulomás betegséget (CGD) a NADPH-oxidáz genetikusan meghatározott defektusa okozza, amely gátolja a granulocytákban és a mononukleáris phagocytákban az extracellularis térből felvett oxigén toxikus metabolitokká történő átalakítását. Az extracellularis killing mechanizmusok károsodása elsősorban a bőrt, a tüdőt és a nyirokcsomókat érintő gennyes gyulladáshoz vezet, és jellemző a granulomaképződés. CGD-ben előfordulhat súlyos ínygyulladás vagy enyhe fokú már a pubertas előtt jelentkező parodontitis [37, 38]. A Papillon-Lefêvre-szindrómát a katepszin $\mathrm{C}$ fehérjét kódoló gén mutációja okozza, aminek következtében károsodik a neutrophil granulocyták kemotaxisa, és csökken a hámsejtek regenerációs képessége. Jellemző a palmoplantaris hyperkeratosis és a tejfogazatot is érintő súlyos parodontitis, amely gyakran a fogak elvesztésével jár [39]. Phagocytadefektusokban különösen fontos a rendszeres parodontológiai gondozás, a fokozott szájhigiéné, a rendszeres fogkő-eltávolítás (depurálás) és a fogfelszínek lesimítása (polírozás).

A természetes immunitás veleszületett zavarai: A krónikus mucocutan candidiasis (CMC) prezentációs tünete a bőrt és a nyálkahártyafelszíneket érintő gombás fertőzés $[40,41]$. A mucocutan candidiasisra hajlamosító immundeficientiák közül ACT1-deficientiában észlelhető még intraoralis tünet macroglossia formájában.

Autoinflammatiós betegségek: A lázszindrómák bizonyos típusaiban (például mevalonát-kináz-deficientia, Muckle-Wells-szindróma) gyakori a stomatitis aphthosa [42, 43]. Az úgynevezett krónikus atipusos neutrophil dermatosis lipodystrophiával és emelkedett testhömérséklettel (CANDLE-) szindrómára microdontia és microstomia jellemző. A fogak kisebb mérete miatt azok a fogívben résesen helyezkednek el [44]. Összehasonlításképpen megemlítjük, hogy autoimmun kórképekben a leggyakoribb tünet a szájszárazság, amely további szájüregi elváltozások rizikótényezője lehet, így gyakori a szájnyálkahártya-fekély, továbbá a petechia és a lichenoid elváltozás [45].

\section{Megbeszélés}

Veleszületett immunhiány-betegségekben a szájüregi tünetek gyakoriak, és nem egy esetben sokkal korábban figyelmeztetnek az immunhiányos állapot fennállására, mint ahogyan az egyéb tünet alapján diagnosztizálható 
lenne. A rendszeres fogászati ellenőrzés tehát egy esetlegesen háttérben megbújó szisztémás betegség, például immundeficientia felismerése miatt is fontos, így gyanú esetén lehetôség nyílik a beteg idejekorán történő immunológiai kivizsgálására.

Anyagi támogatás: A közlemény megírása, illetve a kapcsolódó kutatómunka anyagi támogatásban nem részesült.

Szerzői munkamegosztás: Sz. M.: A betegek vizsgálata, az adatok feldolgozása. E. M.: A kézirat megszövegezése, megszerkesztése, az irodalmi adatok feldolgozása. T. I.: A betegek vizsgálata, a kézirat megszövegezése. A cikk végleges változatát mindhárom szerző elolvasta és jóváhagyta.

Érdekeltségek: A szerző́knek nincsenek érdekeltségeik.

\section{Irodalom}

[1] Szczawinska-Popolonyk A, Gerreth K, Breborowicz A, et al Oral manifestations of primary immune deficiencies in children. Oral Surg Oral Med Oral Pathol Oral Radiol Endod. 2009; 108: e9-e20.

[2] Nualart Grollmus ZC, Morales Chávez MC, Silvestre Donat FJ. Periodontal disease associated to systemic genetic disorders. Med Oral Patol Oral Cir Bucal. 2007; 12: E211-E215.

[3] Tar I, Kiss C, Maródi L, et al. Oral and dental conditions of children with selective IgA deficiency. Pediatr Allergy Immunol. 2008; 19: 33-36.

[4] Grimbacher B, Holland SM, Gallin JI, et al. Hyper IgE syndrome with recurrent infections: an autosomal dominant multi system disorder. N Engl J Med. 1999; 340: 692-702.

[5] Bousfiha A, Jeddane L, Picard C, et al. The 2017 IUIS phenotypic classification for primary immunodeficiencies. J Clin Immunol. 2018; 38: 129-143. [Epub 2017 Dec 11]

[6] Picard C, Bobby Gaspar H, Al-Herz W, et al. International Un ion of Immunological Societies: 2017 Primary Immunodeficiency Diseases Committee report on inborn errors of immunity. J Clin Immunol. 2018; 38: 96-128. [Epub 2017 Dec 11]

[7] Armitage GC. Development of a classification system for periodontal disease and conditions. Ann Periodontol. 1999; 4: 1-6.

[8] Hajishengallis G. Immunomicrobial pathogenesis of periodontitis: keystones, pathobionts, and the host response. Trends Immunol. 2014; 35: P3-P11.

[9] Zijnge V, van Leeuwen MB, Degener JE, et al. Oral biofilm architecture on natural teeth. PLoS ONE 2010; 5: e9321.

[10] Dinauer MC. Primary immune deficiencies with defects in neutrophyl function. Hematology Am Soc Hematol Educ Program 2016; 2016: 43-50

[11] Majorana A, Notarangelo LD, Savoldi E, et al. Leukocyte adhesion deficiency in a child with severe oral involvement. Oral Surg Oral Med Oral Pathol Oral Radiol Endod. 1999; 87: 691-694.

[12] Moutsopoulos NM, Chalmers NI, Barb JJ, et al. Subgingival microbial communities in leukocyte adhesion deficiency and their realtionship with local immunopathology. PLoS Pathog. 2015; 11: e1004698.

[13] Manji F, Dahlén G, Fejerskov O. Caries and periodontitis: contesting the conventional wisdom on their etiology. Caries Res. 2018; 52: 548-564.

[14] Elhennawy K, Manton DJ, Crombie F, et al. Structural, mechanical and chemical evaluation of molar-incisor hypomineraliza- tion-affected enamel: a systematic review. Arch Oral Biol. 2017; 83: 272-281

[15] Chung Leng Muñoz I, Beltri Orta P. Comparison of cephalometric patterns in mouth breathing and nose breathing children. Int J Pediatr Otorhinolaryngol. 2014; 78: 1167-1172.

[16] Batista EL Jr, Novaes AB Jr, Calvano LM, et al. Necrotizing ulcerative periodontitis associated with severe congenital immunodeficiency in a prepubescent subject: clinical findings and response to intravenous immunoglobulin treatment. J Clin Periodontol. 1999; 26: 499-504.

[17] Malek R, Gharibi A, Khlil N, et al. Necrotizing ulcerative gingivitis. Contemp Clin Dent. 2017; 8: 496-500.

[18] He Y, Chen Q, Li B. ATM in oral carcinogenesis: association with clinicopathological features. J Cancer Res Clin Oncol. 2008; 134: 1013-1020.

[19] Klingberg G, Hallberg U, Óskarsdóttir S. Oral health and 22q11 deletion syndrome: thoughts and experiences from the parents perspectives. Int J Paediatr Dent. 2010; 20: 283-292.

[20] Nyul Z, Hadzsiev K, Andrásofszky Z, et al. DiGeorge syndrome in child born by in vitro fertilization. [DiGeorge-szindróma in vitro fertilizációval született gyermekben.] Gyermekgyógyászat 2005; 56: 153-157. [Hungarian]

[21] Jiao H, Tóth B, Erdôs M, et al. Novel and recurrent STAT3 mutations in hyper-IgE syndrome patients from different ethnic groups. Mol Immunol. 2008; 46: 202-206.

[22] Erdős M, Maródi L. Clinical manifestations in hyper-IgE syndrome. [Klinikai manifesztációk hyper-IgE szindrómában.] Gyermekgyógyászat 2004; 55: 15-25. [Hungarian]

[23] Zhang B, Meng B, Viloria E, et al. The role of epithelial STAT3 in amelogenesis during mouse incisor renewal. Cells Tissues Organs 2018; 205: 63-71.

[24] Costa FS, Silveira ER, Pinto GS, et al. Developmental defects of enamel and dental caries in primary dentition: a systematic review and meta-analysis. J Dent. 2017; 60: 1-7.

[25] O'Connell AC, Puck JM, Grimbacher B, et al. Delayed eruption of permanent teeth in hyperimmunoglobulinemia $\mathrm{E}$ recurrent infection syndrome. Oral Surg Oral Med Oral Pathol Oral Radiol Endod. 2000; 89: 177-185.

[26] Freeman AF, Domingo DL, Holland SM. Hyper IgE (Job's) syndrome: a primary immune deficiency with oral manifestations. Oral Dis. 2009; 15: 2-7.

[27] Atkinson JC, Harvey KE, Domingo DL, et al. Oral and dental phenotype of dyskeratosis congenita. Oral Dis. 2008; 14: 419427.

[28] Reiger Z, Varga G, Tóth B, et al. Molecular diagnosis and therapeutic measures in patients with dyskeratosis congenita. [Dyskeratosis congenita: molekuláris diagnosztika és terápiás lehetőségek.] Orv Hetil. 2010; 151: 285-292. [Hungarian]

[29] Reiger Z, Varga G, Tóth B, et al. Dyskeratosis congenita diagnosed in adulthood. [Felnőttkorban diagnosztizált dyskeratosis congenita.] Gyermekgyógyászat 2010; 61: 66-70. [Hungarian]

[30] Fernandes KS, Kokron CM, Barros MT, et al. Oral manifestations in patients with hypogammaglobulinemia. Oral Surg Oral Med Oral Pathol Oral Radiol. 2012; 114: e19-e24.

[31] Muñoz F, Del Río N, Sóñora C, et al. Enamel defects associated with coeliac disease: putative role of antibodies against gliadin in pathogenesis. Eur J Oral Sci. 2012; 120: 104-112.

[32] Tar I, Nemes É, Nemes J, et al. The role of salivary immunoglobulins (secretory $\operatorname{IgA}, \operatorname{IgM}, \operatorname{IgG}$ ) in caries prevalence and primary B-cell deficiency. [A nyálimmunglobulinok (szekretoros IgA, IgM, IgG) mennyiségének és a cariesprevalencia közötti összefüggés vizsgálata deficienciákban (primer B-sejt).] Fogorv Szle. 1999; 92: 331-338. [Hungarian]

[33] Mooney J, Adonogianaki M, Riggio MP, et al. Initial serum antibody titer to Porphyromonas gingivalis influences development of antibody avidity and success of therapy for chronic periodontitis. Infect Immun. 1995; 63: 3411-3416. 
[34] Chung HY, Lu HC, Chen WL, et al. Immunglobulin G profiles in different forms of periodontitis. J Periodontal Res. 2003; 38: $471-476$.

[35] Ferre EM, Rose SR, Rosenzweig SD, et al. Redefined clinical features and diagnostic criteria in autoimmune polyendocrinopathy-candidiasis-ectodermal dystrophy. JCI Insight 2016; 1: e88782.

[36] Shibutani T, Gen K, Shibata M, et al. Long-term follow-up of periodontitis in a patient with Chédiak-Higashi syndrome. A case report. J Periodontol. 2000; 71: 1024-1028.

[37] Budunelli N, Baylas H, Aksu G, et al. Prepubertal periodontitis associated with chronic granulomatous disease. J Clin Periodontol. 2001; 28: 589-593.

[38] Dar-Odeh NS, Hayajneh WA, Abu-Hammad OA, et al. Orofacial findings in chronic granulomatous disease: report of twelve patients and review of the literature. BMC Res Notes 2010; 3: 37.

[39] Gungor OE, Karayilmaz H, Yalcin H, et al. Oro-dental characteristics of three siblings with Papillon-Lefevre syndrome. Niger J Clin Pract. 2017; 20: 256-260.

[40] Soltész B, Tóth B, Shabashova N, et al. New and recurrent gainof-function STATI mutations in patients with chronic mucocutaneous candidiasis from Eastern and Central Europe. J Med Genet. 2013; 50: 567-578.
[41] Maródi L. Mucocutaneous candidiasis. In: Sullivan KE, Stiehm ER. (eds.) Stiehm's immune deficiencies. Elsevier, London, 2014; pp. 775-802.

[42] Erdős M, Maródi L. Autoinflammatory syndromes - recurrent fever syndromes. [Autoinflammációs szindrómák - visszatérő lázszindrómák.] Focus Medicinae 2010; 12: 3-16. [Hungarian]

[43] Erdős M, Maródi L. Fever and fever syndromes. [Láz és lázszindrómák.] Gyermekorv Továbbk. 2010; 9: 9-11. [Hungarian]

[44] Roberts T, Stephen L, Scott C, et al. CANDLE syndrome: orofacial manifestations and dental implications. Head Face Med. $2015 ; 11: 38$.

[45] Márton K. Oral symptoms of immunologic disorders. Part I. Systemic autoimmune diseases. [Immunológiai kórképek fogorvosi vonatkozásai I. Szisztémás autoimmun betegségek.] Fogorv Szle. 2003; 96: 9-15. [Hungarian]

(Erdős Melinda dr., The Rockefeller University, 1230 York Avenue, Box 163, New York, NY 10065, USA e-mail: merdos@rockefeller.edu)

"Factum fieri infectum non potest." (Plautus) (A megtörténtet nem lehet meg nem történtté tenni.)

Az Orvosi Hetilap 2018, 159, 1812. oldalán (44. szám) megjelent OH-Kvízre két helyes megfejtés érkezett.

A beküldők: Dr. Bíró László (Budapest) és Dr. Pallos Ágnes (Budapest).

A nyerteseknek szívböl gratulálunk.

A nyereményüket - egy, az Akadémiai Kiadó webáruházában kedvezményes vásárlásra jogosító kupont - e-mailen küldjük el. 